\section{Genetic Improvement of Red Pine and \\ Eastern White Pine}

\author{
By D. P. FOWLER and C. C. HEIMBURGER \\ Conoda Department of Fisheries and Forestry, \\ Fredericton, N.B. \\ Retired, formerly \\ Ontario Department of Lands and Forests, \\ Maple, Ontario. \\ ODC $165.3+443.3+453$ \\ ". . . it has already been demonstrated that it is possible \\ to produce strains of white pine resistant to both these \\ pests [blister rust and weevil]."
}

\begin{abstract}
Present knowledge of the genetics of red and white pine is reviewed. The adequacy of the existing program is discussed and suggestions are made concerning the direction that future programs should follow.

Red pine is genetically the least variable of any of the tree species that have been intensively studied. Genetic improvement of the species will be difficult, but by no means impossible. The expected improvement will be small in comparison to that which can be made with other coniferous species, but even a modest improvement may be economically justified where the species is potentially valuable in reforestation. Future research with red pine should concentrate on locating, producing, and utilizing additional genetic variation by: interprovenance and interspecific hybridization; individual tree selection with emphasis on growth rate, branch habit, and site adaption; and long-term studies with mutagenic agents.

White pine is a genetically variable species in which considerable improvement can be made in growth characteristics, and in resistance to white pine blister rust, Cronartium ribicola Fischer, and to white pine weevil, Pissodes strobi (Peck). $A$ good deal of effort has been expended on developing white pines resistant to blister rust. This resistance appears to be controlled by a large number of small-effect genes. White pine seed orchards have been established for the production of rust-resistant materials. Future work should emphasize combining rust resistance with weevil resistance into types with superior growth rate and growth form.
\end{abstract}

\section{Résumé}

\section{Amélioration génétique du Pin rouge et du Pin blanc de l'Est}

Les auteurs font le bilan des connaissances génétiques sur le Pin rouge et le Pin blanc, discutent de la justesse des programmes actuels de recherches et indiquent la route à suivre pour. l'avenir.

Le Pin rouge, parmi toutes les essences étudiées intensivement, demeure l'essence qui présente le moins de variation génétique. L'amélioration génétique de cette essence sera difficile mais quand même possible; elle n'en demeure pas moins infime par rapport à celle obtenue chez d'autres résineux. Si modeste soit-elle, cette amélioration peut être iustifiée économiquement et jugée rentable pour certains reboisements.

On devra éventuellement intensifier les recherches sur le dépistage, la production et l'utilisation de variations génétiques additionnelles au moyen de croisements interspécifiques, de sélection d'individus (en considérant le taux de croissance, l'habitude de branchage et l'adaptation au milieu) et sur une plus longue échelle, étudier l'effet des agents mutagènes.

Le Pin blanc, par contre, offre plus de variations génétiques; on peut donc améliorer grandement les caractéristiques de croissance et sa résistance soit à la rouille vésiculeuse, Cronartium ribicola Fischer et au charancon Pissodes strobi (Peck). Que d'efforts furent déployés pour' créer des Pins blancs résistant à la rouille vésiculeuse! Apparemment, un grand nombre de gènes à effet limité contrôlerait cette résistance. 
Des vergers à graine produisent déjà des semences de Pin blanc résistant à la rouille. Dans l'avenir, les travaux devront s'efforcer de produire des plants non seulement résistants à la rouille et au charançon, mais à la fois supérieurs tant par leur taux de croissance que par leur forme harmonieuse.

White pine (Pinus strobus L.) and red pine (P. resinosa Ait.) are important reforestation species in Ontario and Quebec. Only white spruce (Picea glauca (Moench) Voss.) has been used more extensively than red and white pine in reforestation of abandoned farm land. For artificial regeneration of forest land, only Douglas fir (Pseudotsuga menziesii (Mirb.) Franco), white spruce, and jack pine (Pinus banksiana Lamb.) have been planted more widely.

Since the late 1800 's, approximately 145,000 acres of abandoned farm land and forest land in Canada have been planted to red pine and 140,000 acres have been planted to white pine (Cayford and Bickerstaff 1968). Virtually all planting of these species is being done in Ontario and Quebec.

Since the natural breeding systems of red and white pines are quite different, the breeding work with these species will be discussed separately.

\section{RED PINE}

\section{What do we know?}

Soon after the first efforts in forest planting on abandoned farm land during the latter part of the 19th century, red pine was recognized to be exceptionally well suited for this purpose. Because of its late flushing, drought resistance and adaptability to nursery practices, it can be established more successfully in plantations than several other conifers that are commonly used in eastern Canada. Its uniformity of growth rate and generally good growth form make it suitable for mechanical thinning and artificial pruning. The main drawbacks of red pine as a reforestation species are scarcity of seed supply from natural stands, largely because of infrequent good seed crops, and some difficulties with damping-off of seedlings, especially in nurseries established on calcareous sand or watered with "hard" water. Branch thickness is often excessive, especially when grown in open stands, and is a drawback in the production of lumber and veneer as well as pulpwood. With many older plantations supplementing the seed crop from natural stands, seed supply is becoming less critical. Improved nursery techniques are also gradually reducing the hazards of seedling production. The excessive branchiness of red pine can be alleviated by close planting and early and frequent pruning, but branchiness must still be regarded as a major drawback of this species.

The European pine shoot moth, (Rhyacionia buoliana (Schiff.)), can no longer be regarded as a limiting pest of red pine planted on suitable sites.
The serious attacks by this insect experienced in Ontario and adjacent United States some 15 years ago have largely subsided. More recent infestations by this insect in the Maritimes will probably subside. Heikkenen and Miller (1960) suggest that, in the Lake States, it is safe to plant red pine on sites where it will grow 15 inches or more per year.

Red pine is apparently a very old species, having existed for the past 100 million years almost unchanged morphologically (Chaney 1954). It is the only North American representative of the subsection Sylvestres and evidently is not closely related to any other pine species. Attempts to cross red pine with other pines have been unsuccessful. The only hybrid with red pine thus far obtained is Pinus nigra var. austriaca (Hoess) Asch. and Graebn. x P. resinosa produced at Placerville, California (Critchfield 1963). Many attempts to repeat this cross have failed and it has not been possible to backcross the hybrid to the red pine parent (Critchfield 1963).

Red pine is exceptionally uniform morphologically (Rudolf 1957; Wright, Bull and Mitschelen 1963). There is no evidence of sub-species, varieties or forms, although individuals with fastigiate branching, with unusually slender branches and with suppressed lateral branching are known.

Of all tree species subjected to intensive genetic analysis, red pine exhibits the least variation. Relatively small, though statistically significant differences between red pine of different seed origins (in provenance tests) have been demonstrated in respect to survival (Rudolf 1947), phenology (Rehfeldt and Lester 1966), growth rate (Hough 1952; Wright et al. 1963), photoperiodic response (Vaartaja 1962), lammas frequency (Lester and Rehfeldt 1967), and wood quality (Peterson 1966). Studies of geographic variation have demonstrated only a weak correlation with environmental variables. Seeds from northern provenances may be smaller (Rudolf 1947) and the seedlings may have fewer cotyledons (Fowler 1964), be less sensitive to frost (Rudolf 1949), and produce fewer lammas shoots (Lester and Rehfeldt 1967).

The geographic variation pattern of red pine appears to be predominantly random from stand to stand (Holst 1964). Differences have been shown in height growth between provenances from different climatic regions (Hough 1952), and within climatic regions (Wright et al. 1963). In most tests, the difference in height growth between the overall mean and the mean of the best provenance has been between $5-15 \%$.

Unfortunately, most of the existing provenance tests were established using stock from unreplicated nursery sowings and often no information is available on seed weight or growth of seedlings prior to field planting. Environmental influences such as variation in seedbed density (Wright et al. 1963) and variation in fertility of the soil supporting the parent tree (Youngberg 1952) are known to affect early seedling growth. These influences can mask genetic differences or in some cases may be mis- 
interpreted as genetic variation. It is not known how long these non-genetic effects will persist.

Based on evidence from controlled pollination studies (see Fig. 1) in which inbreeding was used as a technique to evaluate natural genetic variation, Fowler (1965) concluded that little genetic variability is present in red pine. In these studies it was shown that the cone parent had a small but significant effect on survival and dimensional traits while the pollen parent had almost no effect. The differences persisted through the second growth cycle and were interpreted as non-genetic effects. The magnitude of the difference between the overall mean and the mean of the best populations, e.g. $8-14 \%$ for second cycle height growth, are comparable to those reported for young provenance material.

While there is general agreement among tree breeders that red pine is less variable than other coniferous species, an unresolved difference of opinion exists concerning the amount of variation and the justification for further tree improvement work with this species. Lundgren and King (1965) showed that even when only very modest improvement of red pine ( $2 \%$ increase in site index) could be attained, improvement programs could be justified economically.

"The feasibility of genetic improvement in red pine is largely contingent on incorporation of small amounts of genetic gain in large numbers of seedlings." (Fowler and Lester 1969). In essence, only where red pine is potentially an important reforestation species will a tree improvement program be warranted. In all of Canada, only 12 thousand acres of red pine were planted in 1965 (Cayford and Bickerstaff 1968). Almost all this planting was done in Ontario. Thus, it is evident that a red pine improvement program may be warranted in Ontario. Even here, an action program aimed at mass producing genetically improved material is difficult to justify unless more red pine are produced than currently planned. Money and effort spent on improving red pine might yield considerably greater returns if expended on other reforestation species.

\section{What do we want, and how do we get it?}

Ideally we would like to have red pines which have fine branches, and an improved growth rate, and which are adaptable to a wider variety of sites than those presently found in natural stands. These trees should retain the generally high resistance to attack by white pine weevil (Pissodes strobi (Peck)) and sweetfern blister rust (Cronartium comptoniae Arth.), as well as the many other desirable attributes already found in natural populations (e.g. good form and ease of handling in the nursery and plantations).

Individual tree selection, with progeny testing is the most promising approach to producing genetically improved red pine. Progeny testing is essential. Mass production of seeds can be accomplished by either clonal or seedling seed orchards. Because of the need for progeny testing of selected trees,

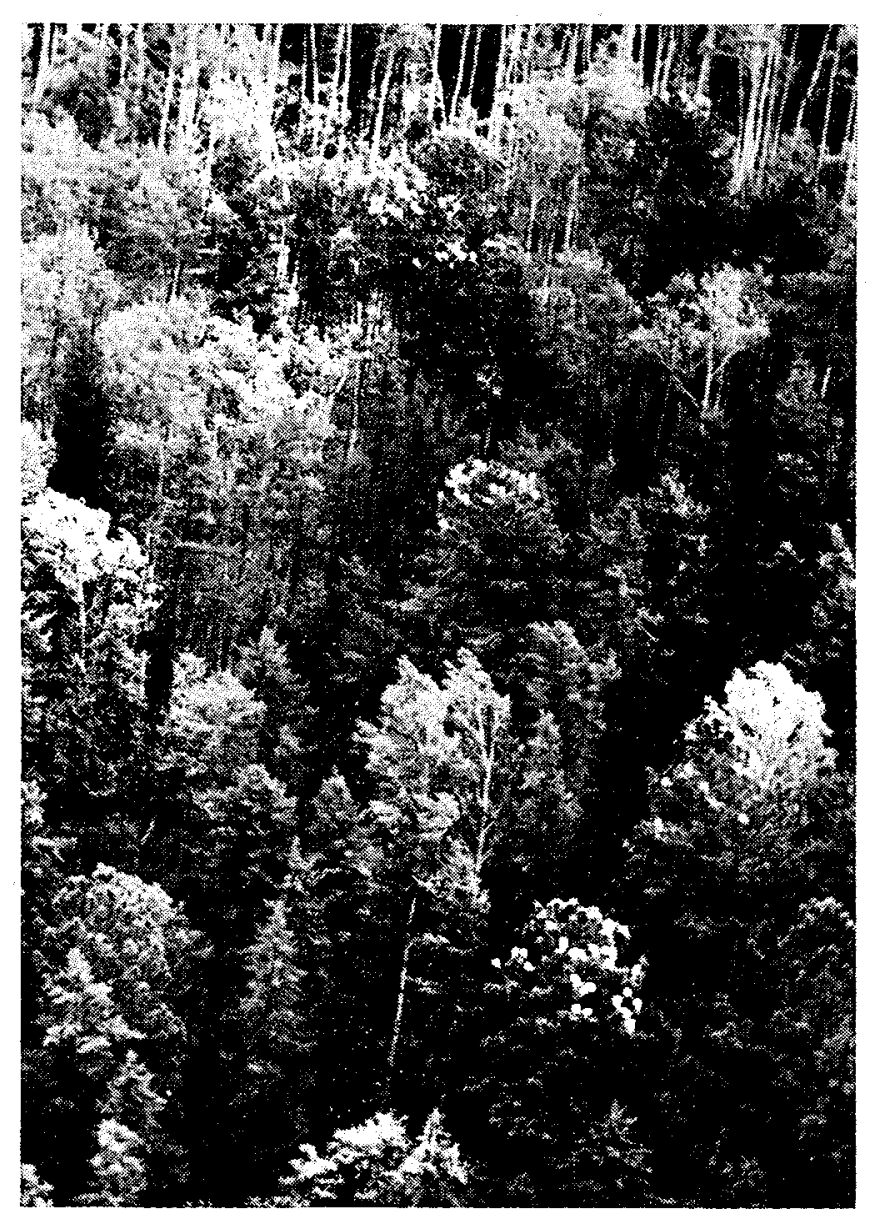

Fig. 1. Controlled pollination bags in crowns of mature red pines near Swastika, Ontario. Photo by Department of Fisheries and Forestry, Petawawa Forest Expt. Sto., Chalk River, Ontario.

the progeny test and seedling seed orchard approach suggested by Wright and Bull (1963) should be considered.

In the absence of such programs, or until such programs begin to produce seeds on a commercial scale, the following rules should be followed in procuring red pine seed:

1. Board seed zones (e.g. those used by Ontario Department of Lands and Forests) should be used to restrict long distance transfers of seeds or seedlings. In time of seed shortage in one zone, seeds from adjacent zones may be substituted.

2. Seeds may be collected from any good healthy stand or from plantations where such stands are not available.

The limited genetic variation available within red pine is a major obstacle to improvement of this species. Research programs already in progress will contribute considerably to an understanding of red pine population structure. New research in red pine should be aimed at locating, producing, and utilizing additional genetic variation. For example:

1. Interprovenance hybridization should be further explored as a means of increasing red pine growth as well as a source of additional variation for selection of other attributes, e.g. site adaptability and branching. Interpollination of extreme southern and northern, and eastern and western populations should be attempted. 
2 Selection of outstanding trees in natural populations, with emphasis on growth rate, branch habit, and adaption to specific sites should be continued. In this respect, the Ontario Department of Lands and Forests already has selections for fine branching. Grafts from these selections retain the habit of the original tree, indicating that fine branching is under strong genetic control (broad sense heritability). A seedling orchard has already been established with some of this material. As red pine does not suffer from inbreeding depression (Fowler 1965), it should be possible to establish clonal orchards using only two or three selected clones.

3. Additional attempts, using new techniques, e.g. organ culture, should be made to hybridize red pine with other pine species.

4. Consideration should be given to long-term studies aimed at inducing new variation in red pine, e.g. the use of irradiation and other mutagenic agents.

In addition to the above, further studies designed to separate genetic from environment-induced variation, e.g. maternal effects, should be undertaken.

In summary, because of the general paucity of variation, red pine will be a difficult, but by no means impossible, species to improve genetically. The improvement in this species will be relatively small in comparison to expected improvement of other coniferous species. But even a modest improvement may be justified (Lundgren and King 1965) especially when the species is widely planted.

\section{WHITE PINE}

\section{What do we know?}

White pine has, for a long time, been one of the most valuable timber trees in eastern Canada. It was at one time used quite extensively in reforestation, because seed was easily available and seedling production did not at first encounter serious difficulties. However, heavy attacks by the native white pine weevil and introduced white pine blister rust (Cronartium ribicola Fischer) caused severe damage to some of the earliest plantations. Attention was then directed towards the use of red pine and to other native and exotic conifers as possible replacements for white pine. The use of white pine in forest planting was not entirely discontinued. Several very promising plantations indicate the high potential of the species for valuable wood production when grown on suitable sites and under adequate protection from its two most serious pests.

Provenance tests with white pine of different geographic origin were the forerunners of more recent breeding work. The earliest trial of white pine was established in the United States in 1937 (Pauley, Spurr and Whitmore 1955). This trial included white pine from three Ontario sources. The results indicated that the farther the seed collection was made from the planting area (Petersham, Mass.), the poorer the growth. Less weevil damage oc- curred in material from the Ontario provenances, but it was considered that this was related to slower growth.

A white pine breeding program was initiated by the Ontario Department of Lands and Forests in 1946. Seed was collected in 1947 and 1948 from several stands in Ontario for a provenance test which was to serve as a basis for more intensive breeding work. The results from this test indicate that the more southern provenances grow more rapidly than the more northern ones. One provenance, growing on wet sand on the east shore of Lake Huron, is the only one showing satisfactory growth on a similar site in eastern Ontario and may indicate the existence of a site ecotype.

In 1955, the U.S. Forest Service organized a range-wide test to further study geographic variation in white pine. Four U.S. Forest Service Experiment Stations and the Ontario Department of Lands and Forests cooperated in this study. Most of our information on geographic variation in white pine has been derived from this study. It has been shown that when southern provenances are compared with northern provenances, the southern seed requires longer stratification (Fowler and Dwight 1964) and southern seedlings require a longer cold treatment to break dormancy (Mergen 1963), have longer needles (Mergen 1963), continue shoot growth longer into the summer (Santamour 1960), and are faster growing (Sluder 1963; Funk 1965). Only at the most northern test site, Ganaraska Forest, Ontario, have the southern provenances been adversely affected by severe climatic conditions (Fowler and Heimburger 1969). One provenance from Norfolk County on the north shore of Lake Erie has performed exceptionally well in a test in Maryland (Genys 1968).

These provenance tests indicate that the species exhibits moderate geographic variation, i.e. less variation than jack pine and Scots pine (P. silvestris L.) would have shown within a geographic area of comparable size and physiographic and climatic variation. There is also some evidence of a maritime ecotype of white pine (Mergen 1963). Evidence to date indicates that increased growth can be attained by using seeds of more southern origins. This approach should be pursued with caution as most provenance tests have not been in existence long enough to confirm these conclusions. On the basis of present knowledge, seed movements should be confined to within broad seed zones (e.g. those used by Ontario Department of Lands and Forests).

\section{What do we want and how do we get it?}

Work on the breeding of white pine has been in progress in Canada since 1937 (Heimburger 1956). Almost all the early studies were concerned with developing white pines resistant to blister rust and, to a lesser extent, to white pine weevil. Only in recent years have other characteristics, such as growth rate, received much consideration. Work on white pine has been centered in Ontario; 1937-46 
at the Petawawa Forest Experiment Station and Ottawa and since 1946 at Maple.

In marked contrast to red pine, white pine is largely out-pollinating, carries a fairly heavy load of deleterious recessive genes, revealed by inbreeding made possible by fairly high self-compatibility (Fowler 1965). Thus most of the advantages and drawbacks of breeding work with an outpollinating species (Allard 1960) are applicable to white pine. The aim of tree breeding should be the production of synthetic varieties with their component parts rigidly selected for resistance to the two major pests, with superior growth rate and growth form, coupled with slightly wider climatic and site adaption (Heimburger 1962).

\section{Resistance to blister rust:}

Breeding for resistance to white pine blister rust has followed two lines, 1) selection and breeding within eastern white pine and 2) incorporation of rust resistance genes into a hybrid between white pine and rust-resistant exotics.

In the intraspecific selection and breeding program, phenotypically resistant trees are selected in areas of moderate to severe rust incidents. Scions from these trees are grafted on seedling stock and inoculated with rust to eliminate rust-susceptible individuals (Fig. 2). Clones surviving this test are then evaluated by full-sib (both parents known) progeny tests to determine the clones ability to transmit rust resistance. When enough resistancetransmitting clones are obtained, clonal seed orchards are established to mass produce rust-resistant seed. To date, 30 acres of clonal seed orchards have been established in Ontario (Dyer 1969).

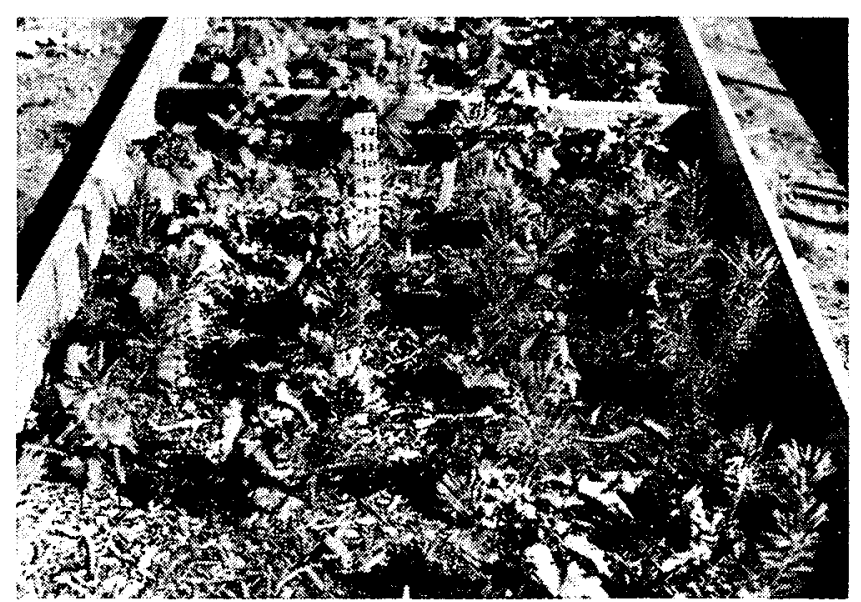

Fig. 2. White pine grafts in blister rust inoculotion beds. Note the Ribes cuttings growing beside eoch groft. Photo by Ontario Department of Lands and Forests, Southern Research Station, Maple, Ontario.

Resistance to white pine blister rust appears to be controlled by a large number of small-effect genes. No evidence of dominant resistance has been located within eastern white pine. The problem then is one of individual tree selection, testing for rust resistance, and full-sib progeny testing to determine combining abilities. Large numbers of selections have been made and many of these have already been tested for resistance by the Ontario
Department of Lands and Forests. The program of full-sib progeny testing has only been completed for a small number of selections.

Mass selection for rust resistance is also possible. Large numbers of seedlings derived from seeds of desirable geographic origins can be inoculated. The surviving seedlings are retained for further clonal testing and may be used for establishing seed orchards. Dyer (1969) describes a 2-acre seedling seed orchard obtained by a slight modification of this technique. This seedling seed orchard is producing seeds and seedlings which are expected to be somewhat less than $20 \%$ resistant to blister rust.

There is no evidence of geographic differences in blister rust susceptibility in white pine.

Eastern white pine is the only northeastern American representative of the subgenus Haploxylon, series Strobi. It crosses readily with P. monticola Dougl., P. peuce Griseb., P. griffithii McClelland, and P. parviflora Sieb. and Zucc. (Heimburger 1956). It can also be crossed with P. flexilis James, and P. ayacahuite Ehrenb. (Wright 1959). Crosses between white pine and other Haploxylon pines are difficult if not impossible to attain.

In the interspecific approach to breeding for rust resistance, hybrids are produced using controlled pollination techniques. These hybrids are then evaluated by subjecting them to severe blister rust conditions. If rust-resistant hybrids are located, techniques for mass-producing hybrids can be developed. More often, the hybrid will be backcrossed to white pine and subjected to further selection for rust resistance and desirable growth characteristics.

Attempts to incorporate resistance into a first generation hybrid between white pine and rustresistant exotics has been unrewarding. In most hybrids, resistance appears to be additive and thus the hybrids are usually intermediate between the two parents in rust resistance. Only in one instance is there evidence for strong rust resistance transmission by a clone of $\mathbf{P}$. griffithii, simulating a single gene control in the first generation hybrids with white pine. All subsequent backcrosses of these hybrids to white pine indicate strong but variable rust resistance based on several genes ${ }^{11}$.

\section{Resistance to weeviling:}

Although breeding for weevil resistance has been included as part of the white pine breeding program since its inception, little work aside from phenotypic selection was carried out until 1956 when actual testing was begun (Heimburger 1963; Sullivan 1966). In this work, scions from trees selected for resistance to blister rust have been fieldgrafted in an area of high weevil incidence and the selections evaluated on the basis of weevil damage.

Experience to date indicates that individual tree selection and clonal testing for weevil resistance can be used to locate resistant trees. No seedling

\footnotetext{
2) Information on file, Ontario Deportment of Lands and Forests, Maple, Ontario.
} 
progeny testing for weevil resistance has been completed, but a fairly high broad sense heritability of characteristics affecting weevil resistance is indicated by the grafts mentioned above (Heimburger and Sullivan 1969). Clonal materials could be of considerable value if satisfactory vegetative propagation techniques were developed.

Movement of seed northward by one zone should be acceptable although this may result in increased weevil susceptibility (Fowler and Heimburger 1969). There is some evidence to suggest that decreased weevil susceptibility can be attained by moving northern seed south (Pauley et al. 1955; Heimburger 1956).

Breeding for resistance to white pine weevil poses quite a different problem than breeding for resistance to blister rust. Firstly, it is very expensive to test for weevil resistance in comparison with testing for rust resistance and secondly, testing techniques have not been perfected to the same degree. Criteria of selection for weevil resistance similar to those suggested by Stroh and Gerhold (1965) should be developed to avoid testing large quantities of non-resistant materials. Although it has been demonstrated that selection for weevil resistance is possible, it is doubtful if any largescale action program should be undertaken until adequate selection and testing techniques have been developed.

\section{Prospects for further genetic improvement}

Largely because of the difficulties encountered with white pine, most notably blister rust and weevil damage, it has lost favor as a reforestation species. It is doubtful if any organization in Canada can justify a tree improvement program in white pine if the attitude towards the species remains as negative as it seems to be at present. On the other hand, it has already been demonstrated that it is possible to produce strains of white pine resistant to both these pests.

Within the natural range of white pine, from western Ontario to the Atlantic coast, there is

\section{References}

ALLARD, R. W. 1960. Principles of plant breeding. John Wiley and Sons, New York. 485 pp.

CAYFORD J. H. and A. BICKERSTAFF. 1968. Man-made forests in Canada. Can. Dep. Fish. Forest., Forest. Br. Publ. 1240. $68 \mathrm{pp}$.

CHANEY, R. W. 1954. A new pine from the Cretaceous of Minnesota and its paleoecological significance. Ecology 35: $145-151$

CRITCHFIELD, W. B. 1963. The Austrian $X$ red pine hybrid. Silvae Genet. 12: 187-192.

DYER, W. G. 1969. Seed orchards and seed production areas in Ontario. Proc. 11th Meeting Comm. Forest Tree Breeding Can. Part 2: 23-27.

FOWLER, D. P. 1964. Effects of inbreeding in red pine, Pinus resinosa Ait. Silvae Genet. 13: 170-177.

FOWLER, D. P. 1965. Effects of inbreeding in red pine, Pinus resinosa Ait., II Pollination studies, Silvae Genet. 14: $12-23$.

FOWLER, D. P. and T. W. DWIGHT, 1964. Provenance differences in the stratification requirements of white pine. Can. J. Bot. 42: 669-675.

FOWLER, D. P. and C. HEIMBURGER. 1969. Geographic variation in eastern white pine, 7-year results in Ontario. Silvae Genet. 18: 123-129.

FOWLER, D. P. and D. T. LESTER. 1969. The genetics of red pine. U.S. Dep. Agr., Forest Serv., Res. Pap. in press. ample opportunity for further genetic improvement of this valuable forest tree. It will be the task of the various organizations (federal, provincial, and industrial) at the policy-making level to direct further genetic improvement of white pine.

The Ontario Department of Lands and Forests has succeeded in accumulating a valuable collection of selected eastern white pine and exotic white pine species and hybrids at Maple, Ontario. Most of these trees have been tested for rust resistance and many are now of an age where they can be progeny-tested to determine their combining ability in respect to blister rust resistance. Progeny testing of such selected materials remains one of the most important aspects of this project. Many of these materials have shown to be highly susceptible to weevil attack.

Most of the emphasis in the Ontario program has been placed on breeding for rust resistance. It is now time to increase emphasis on other attributes and to combine rust resistance with weevil resistance into superior types in respect to growth rate and form. The rust inoculation techniques have been perfected to the point where large-scale mass selections can be carried out with seedlings of superior provenances. It is now possible to widen the genetic base of the material.

To maximize the usefulness of improved white pine, it will be desirable to select for weevil resistance among materials already proven to be blister rust resistant. Such rust-resistant materials are already available. The white pine materials from Norfolk County in southern Ontario, mentioned previously, have shown to be more weevil resistant than the bulk of the white pine grown in Ontario. Several full-sib families from selected trees have been screened for resistance to blister rust and found to contain about 1 resistant seedling in each 1000 seedlings tested. These seedlings appear even more promising for combined resistance breeding than materials already selected for resistance to blister rust. Work at the interspecific level also offers promise of obtaining additional combined resistance.

FUNK, D. T. 1965. Southern Appalacian white pine off to a good start in the midwest. Proc. 4th Cent. States Forest Tree Impr. Conf.: 26-28.

GENYS, J. B. 1968. Geographic variation in eastern white pine. Two-year results of testing range-wide collections in Maryland. Silvae Genet. 17: 6-12.

HEIMBURGER, C. 1956. White pine tree improvement in Canada. Rep. Conf. on White Pine Tree Impr. Concord, N. H., April 24, 1956: 9-14.

HEIMBURGER, C. 1962. Breeding for disease resistance in forest trees. Forest. Chron. 38: 356-363.

HEIMBURGER, C. 1963. The breeding of white pine for resistance to weevil. FAO/FORGEN 63, 6b/5. 2pp.

HEIMBURGER, C. C. and C. R. SULLIVAN. 1969. Screening of Haploxylon pines for resistance to the white pine weevil (Pissodes strobi Peck) I. Some comparative observations on the resistance of Pinus peuce Griseb. and $P$. strobus $L$. to the white pine weevil. In press.

HEIKKENEN, H. J. and W. E. MILLER. 1960. European pine shoot moth damage as related to red pine growth. U.S. Dep. Agr., Forest Serv., Lake States Forest Exp. Sta., Sta. Pap. 83. 12 pp.

HOLST, M. J. 1964. Forest tree breeding and genetics at the Petawawa Forest Experiment Station. Proc. 9th Meeting Comm. Forest Tree Breeding Can. Ii: 63-96.

HOUGH, A. F. 1952. Preliminary results of red pine seed- 
source tests in northwestern Pennsylvania. U. S. Dep. Agr., Forest Serv., Northe. Forest Exp. Sta., Sta. Pap. 49 $28 \mathrm{pp}$.

LESTER, D. T. and G. E. REHFELDT. 1967. Frequency of lammas growth in a provenance test of red pine. Can. J. Bot. 45: 833-838

LUNDGREN, A. L. and J. P. KING. 1965. Estimating financial returns from forest tree improvement programs. Proc. Soc. Amer. Forest:: 45-50.

MERGEN, F. 1963. Ecotypic variation in Pinus strobus $L$. Ecology 44: 716-727.

PAULEY, S. S., S. H. SPURR and F. W. WHITMORE. 1955 Seed source trials of eastern white pine. Forest Sci. 1: 144-256.

PETERSON, T. A. 1966. Variation in radial growth patterns and specific gravity of red pine (Pinus resinosa Ait.). PhD. dissertation, Univ. Wis., Madison, Wis. $191 \mathrm{pp}$.

REHFELDT, G. E. and D. T. LESTER. 1966. Variation in shoot elongation of Pinus resinosa Ait. Can. J. Bot. 44: 14571469.

RUDOLF, P. O. 1947. Importance of red pine seed source. Proc. Soc. Amer. Forest.: 384-398.

RUDOLF, P. O. 1949. Winter damage and seed source of planted pines. Proc. Minn. Acad. Sci. 17: 74-79.

RUDOLF, P. O. 1957. Silvical characteristics of red pine. U. S. Dep. Agr., Forest Serv., Lake States Forest Exp. Sta., Sta. Pap. 44. 32 pp.

\section{Forest Genetics Tour}

\section{in Europe}

\section{By O. Sziklai*}

Associate Professor, Faculty of Forestry, University of British Columbia,

Vancouver 8, B.C.

Sixteen third-year Forestry students from the University of British Columbia completed a threeweek tour in Europe during May. They studied forest genetics and tree breeding methods in six countries. Prior to their departure, a one-week seminar was arranged on the U.B.C. Campus to acquaint the students not only with the forestry but also the geographical, political and economical aspects of the countries to be visited. Diplomatic representatives from the six countries were invited and talked to the students during the seminar.

The trip commenced in the United Kingdom where the Alice Holt Forest Research Station of the British Forestry Commission was visited. This year the Forestry Commission celebrated its 50th anniversary and the students were the first who received publications prepared especially for this purpose.

In France, around Nancy and the Vosges mountains, Professor Bouvarel was the leader of the tour. Besides exposing the students to tree breeding work in France, he arranged for them to share half a day with a group of French Forestry students who were also visiting the same districts.

In West Germany, the Institute of Forest Genetics at Schmalenbek was visited. The central building of this Institute, completed at the beginning of 1968 , is equipped with the most modern instruments for forest genetics research. The Pein and Pein Forest Nursery Co. presented an afternoon program at Halstenbek in their 450 acre forest nursery where they produce 200 million seedlings yearly.

Three days were spent in Denmark visiting the State College for Rangers at Hillerod, the forest district in the southern part of Sjaelland and to the Tree Breeding Institute and the Danish State Forestry
SANTAMOUR, F. S. Jr. 1960. Seasonal growth in white pine seedlings from different provenances. U. S. Dep. Agr., Forest. Serv., Northe. Forest Exp. Sta., For. Res. Notes 105. 4 pp.

SLUDER, E. R. 1963. A white pine provenance study. U. S. Dep. Agr., Forest Serv., Southe. Forest Exp. Sta., Res. Pap. SE-2, 16 pp.

STROH, R. C. and H. D. GERHOLD. 1965. Eastern white pine characteristics related to weevil feeding. Silvae Genet. 14: $160-169$.

SULLIVAN, C. R. 1966. Testing pre-selected grafts for resistance to white pine weevil, Pissodes strobi Peck. Proc. 10th Meeting Comm. Forest Tree Breeding Can. II: 145. 150.

VAARTAJA, O. 1962. Ecotypic variation in photoperiodism of trees with special reference to Pinus resinosa and Thuja occidentalis. Can. J. Bot. 40: 849-856.

WRIGHT, J. W. 1959. Species hybridization in the white pines. Forest Sci. 5: 210-222.

WRIGHT, J. W. and W. I. BULL. 1963. A one-parent progeny test and seed orchard for the improvement of red pine. J. Forest. 61: 747-750.

WRIGHT, J. W., W. I. BULL and G. MITSCHELEN. 1963. Geographic variation in red pine, 3-year results. Mich. Agr. Exp. Sta., Quart. Bull. 45: 622-630.

YOUNGBERG, C. T. 1952. Effect of soil fertility on the physical and chemical properties of tree seed. J. Forest. 50: $850-852$.
Seed Extracting Plant Tree Improvement Station at Humelbaek. The students had a chance to meet the "father of forest genetics" C. Syrach Larsen.

The Malingsbo State Forest District provided an excellent insight into the intensive silvicultural work and the wildlife and recreation arrangements in Sweden. Professor Risto Sarvas was the guide at Punkaharju Experiment Station in Finland. EnsoGutzeit $\mathrm{Oy}$ Co., one of the largest companies showed their silvicultural projects to the students. The Central Forestry Association Seed Orchards at Tapio and the tree breeding work at the Foundation for Forestry Breeding. Haapastensyrja Breeding Center, illustrated a completely different dimension of tree breeding to the students than had been seen in other countries. The clearly defined objectives, the large scale and coordinated program, had an impressive effect on them.

The tour was largely financed by the students themselves with substantial help in the form of $\$ 4,000$ provided by Dr. Walter Koerner, Chairman of the Board of Governors, University of British Columbia and the U.B.C. Alumni Association.

The students gained first-hand information on intensive forest management approaches in the countries where forestry has been practiced for more than 300 years. Besides acquiring the professional information, they became familiar with cultural institutions and social customs in the six countries visited. After their written reports are completed, they plan to give seminars and to discuss their impressions with classmates and with practicing foresters.

"A man's mind stretched by a new idea can never go back to its original dimensions," as Oliver Wendell Holmes said, and as a result of this experience the students have widened the horizons of their education. 